\title{
RANCANG BANGUN APLIKASI RESERVASI SERVICE UNTUK BENGKEL SEPEDA MOTOR BERBASIS WEB
}

\author{
I Gusti Ngurah Agung Widhiananda ${ }^{1}$, I Made Arsa Suyadnya ${ }^{2}$, Komang Oka Saputra ${ }^{3}$ \\ 1,2,3, Program Studi Teknik Elektro, Fakultas Teknik, Universitas Udayana \\ Email: turahagungnanda@gmail,com ${ }^{1}$, arsa.suyadnya@unud.ac.id ${ }^{2}$, \\ okasaputra@unud.ac.id ${ }^{3}$
}

\begin{abstract}
ABSTRAK
Bengkel merupakan salah satu fasilitas usaha yang menyediakan jasa perbaikan purna jual kepada konsumen. Saat ini banyak pihak pengelola bengkel yang menyediakan layanan reservasi service kendaraan untuk melayani pelanggan, namun hingga saat ini reservasi ditangani pengelola bengkel secara manual. Pencatatan secara manual sangat menyulitkan pihak bengkel ketika harus memberikan sebuah informasi kepada pelanggan perihal jadwal service. Penelitian ini membangun sebuah aplikasi reservasi service untuk bengkel sepeda motor berbasis web. Aplikasi ini dibangun dengan bahasa pemrograman PHP dan database MySQL yang telah didukung web responsive design. Aplikasi yang dihasilkan mengakomodasi kebutuhan banyak bengkel untuk menyediakan layanan reservasi service. Melalui aplikasi ini, pihak bengkel dapat melakukan manajemen layanan reservasi service, pihak pelanggan dapat memilih bengkel yang tersedia berdasarkan jarak terdekat pelanggan ke bengkel dan pelanggan dapat juga memilih hari dan jam reservasi yang diinginkan. Berdasarkan hasil pengujian menggunakan metode black box, keseluruhan fungsionalitas aplikasi ini telah dapat berjalan dengan baik.
\end{abstract}

Kata Kunci : Bengkel, Reservasi, Service, Web

\begin{abstract}
Motorbike repair shops are one of the industries which provide services for repairs, tunings, or even providing availability of parts to the customer. Punctuality is one of the most important factor to every users that uses this kind of service. Nowadays, most of the repair shops provide several means to book and to make a reservation for most customer's intended services. But, they are done manually by the management, either by direct visits or by call. This will gradually become a tedious task and requires meticulous book keeping to track a huge numbers of reservations. This research was done as an attempt to develop a responsive web-based system, starting from its basic infrastructure analysis, built in PHP with standard MySQL database system. The result of this development is intended to cater and accommodate the needs of customers for reserving services ahead as well as to find the nearest, most suitable shops for their appointments automatically. All of this system functionalities are working as intended according to black box testing method.
\end{abstract}

Keywords : Repair Shops, Reservation, Service, Web

\section{PENDAHULUAN}

Bengkel merupakan salah satu fasilitas usaha yang menyediakan jasa perbaikan purna jual kepada konsumen. Bengkel sepeda motor belakangan ini menjadi salah satu tempat favorit para konsumen untuk melakukan service atau perbaikan pada kendaraan. Ketepatan waktu merupakan hal yang sangat penting bagi para pengguna jasa perbengkelan. Bengkel menyediakan berbagai macam jasa pelayanan, diantaranya layanan jasa service dan penyediaan suku cadang resmi.

Saat ini banyak pihak pengelola bengkel yang menyediakan layanan reservasi service kendaraan untuk melayani pelanggan, namun reservasi dilakukan oleh pengelola bengkel secara manual. Para pelanggan yang ingin melakukan reservasi service kendaraannya harus datang langsung ke bengkel maupun melalui telepon dan SMS, kemudian pihak bengkel mencatat nama pelanggan dan 
urutan reservasi pada sebuah buku. Hal ini menjadi masalah ketika jumlah antrean pelanggan cukup banyak, sehingga bengkel tidak dapat melayani semua pelanggan tersebut.

Pencatatan secara manual tersebut sangat menyulitkan pihak bengkel ketika harus memberikan sebuah informasi kepada pelanggan perihal jadwal service. Selain kesulitan dari sisi pihak bengkel, kesulitanpun dialami oleh pihak pelanggan dimana pada bengkel yang dituju. Kuota yang disediakan oleh pihak bengkel terkadang telah melebihi batas maksimum yang disediakan dan pelangganpun harus mencari bengkel lain atau harus melakukan penjadwalan ulang di hari berikutnya.

Perkembangan teknologi informasi dan pemanfaatannya di berbagai bidang dapat digunakan sebagai solusi untuk mengatasi permasalahan reservasi service. Salah satu pemanfaatan teknologi informasi adalah dengan membangun suatu sistem reservasi yang terkomputerisasi untuk memudahkan pelanggan melakukan reservasi service kendaraannya. Penelitian mengenai pengembangan aplikasi reservasi telah dilakukan penelitian-penelitian lain, antara lain : penelitian yang dilakukan oleh Sukerti, dkk [1]. Sukerti, dkk. membangun Sistem Informasi Reservasi Speedboat Berbasis Web Service dan SMS Reply. Aplikasi yang dibangun digunakan untuk memberi kemudahan kepada masyarakat dalam mengakses informasi akurat terkait speedboat, antara lain jadwal, harga tiket, reservasi tiket, dan data tiap speedboat (nahkoda, kapasitas tempat duduk, fasilitas keamanan). Penelitian berikutnya dilakukan oleh Aryani [2] yang merancang sebuah sistem informasi reservasi dan pelayanan kamar. Sistem informasi reservasi dan pelayanan kamar ini dapat membantu kegiatan operasional menjadi lebih efektif dan terintergrasi. Sistem informasi reservasi dan pelayanan kamar ini digunakan untuk mempermudah dalam proses pencarian data, penghitungan biaya keseluruhan, dan permudah dalam proses pembuatan laporan. Sehingga dapat menjadi solusi untuk meningkatkan kualitas kegiatan operasional dan juga meningkatkan mutu pelayanan hotel. Penelitian [3] merupakan penelitian mengenau aplikasi web reservasi dan penjualan untuk restoran yang memanfaatkan teknologi smartphone/tablet untuk mengelola pelaksanaan pemesanan konsumen di restoran agar lebih teratur dan lebih akurat, serta dapat menghemat kertas karena pemesanan menu dicatat secara digital.

Untuk memecahkan permasalahan tersebut maka penelitian ini akan membangun sebuah aplikasi reservasi service untuk bengkel sepeda motor berbasis web. Platform web dipilih karena aplikasi berbasis web dapat diakses dengan mudah dari berbagai perangkat cukup menggunakan browser. Aplikasi yang dibangun dapat memberikan informasi mengenai ketersediaan pitstop dan jadwal reservasi service kepada pelanggan. Selain itu, aplikasi ini juga dapat menampilkan lokasi bengkel terdekat dari pelanggan melalui layanan informasi geografis. Melalui aplikasi ini pelanggan dapat memilih jadwal dan lokasi bengkel yang diinginkan. Apabila reservasi berhasil dilakukan sebagai pengingat jadwal service, aplikasi akan mengirimkan notifikasi melalui email. Fiturfitur yang dijabarkan di atas akan mampu menghemat waktu dan biaya baik dari segi pelanggan maupun pihak bengkel.

\section{KAJIAN PUSTAKA}

\subsection{Sistem Informasi}

Sistem informasi adalah serangkaian komponen berupa manusia, prosedur, data, dan teknologi (seperti komputer) yang digunakan untuk melakukan sebuah proses untuk menghasilkan informasi yang bernilai untuk pengambilan keputusan [4]. Informasi dapat didefinisikan sebagai hasil dari pengolahan data dalam suatu bentuk yang berguna dan berarti bagi penerimanya yang menggambarkan suatu kejadian-kejadian yang nyata, dapat digunakan untuk pengambilan keputusan.

\subsection{Metode Pengembangan Sistem Informasi}

Model System Development Life Cycle (SDLC) adalah metodologi untuk merancang, membangun, dan memelihara informasi dan proses sistem. Terdapat banyak model SDLC, salah satunya adalah model Waterfall yang terdiri dari lima tahap untuk secara berurutan diselesaikan dalam rangka untuk mengembangkan solusi 
perangkat lunak [5]. Ada beberapa tahapan (SDLC) :

1. Fase Perencanaan Sistem

2. Fase Analisis Sistem

3. Fase Perancangan Sistem secara Umum

4. Fase Evaluasi dan Seleksi Sistem

5. Fase Perancangan Sistem secara Detail

6. Fase Implementasi Sistem dan Pemeliharaan Sistem

\subsection{Sistem Informasi Geografis (SIG)}

SIG merupakan suatu sistem informasi yang berbasis komputer, dirancang untuk bekerja dengan menggunakan data yang memiliki informasi spasial (bereferensi keruangan) [6]. Objek data yang menjadi sasaran SIG adalah data citra, data lapangan, data survey, peta digital, serta GPS (Global Positioning System). SIG dirancang untuk mengumpulkan, menyimpan dan menganalisa objek-objek dan fenomena dengan lokasi geografi merupakan karakteristik yang penting atau kritis untuk dianalisa. Secara umum algoritma pemrosesan data dari sistem komputer SIG ini ialah input, manipulasi, pengelolaan, query, analisis, dan visualisasi yang terdapat pada Gambar 1.

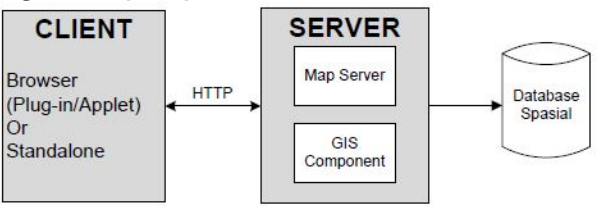

Gambar 1. Arsitektur Minimum Sebuah SIG Berbasis Web

\subsection{Google Maps API}

Google Maps merupakan layanan gratis yang diberikan oleh Google. Google Maps adalah suatu peta dunia yang dapat digunakan untuk melihat suatu daerah dengan menggunakan suatu browser. Google Maps API adalah fungsi fungsi pemrograman yang disediakan oleh Google maps agar dapat diintegrasikan kedalam Web atau aplikasi yang sedang dibuat [7].

\section{Metode Penelitian}

\subsection{Tahapan Penelitian}

Tahapan- tahapan yang dilakukan pada penelitian ini adalah sebagai berikut.

1. Studi kepustakaan
2. Pengumpulan data dengan cara observasi penelitian dan analisis kebutuhan aplikasi

3. Pemodelan sistem dengan menggunakan diagram alir data

4. Perancangan data base

5. Implementasi sistem yang sesuai dengan analisa dan desain sistem

6. Pengujian perangkat lunak

7. Pengambilan kesimpulan dari penelitian yang dilakukan

\subsection{Gambaran Umum Sistem}

Gambaran umum system ini. Gambar 2, menunjukkan proses kerja secara umum yang ada pada aplikasi reservasi servis motor. Aplikasi ini melibatkan tiga pihak yaitu pihak bengkel sebagai pengelola admin bengkel, pihak pelanggan sebagai pelanggan yang ingin melakukan reservasi service, dan pihak penyedia layanan sebagai admin yang mengkonfirmasi pendaftaran, baik yang dilakukan oleh pihak bengkel maupun pihak pelanggan. Bagian server ini juga sebagai database utama sebagai tempat pengelolaan data dari pihak bengkel dan pihak pelanggan.

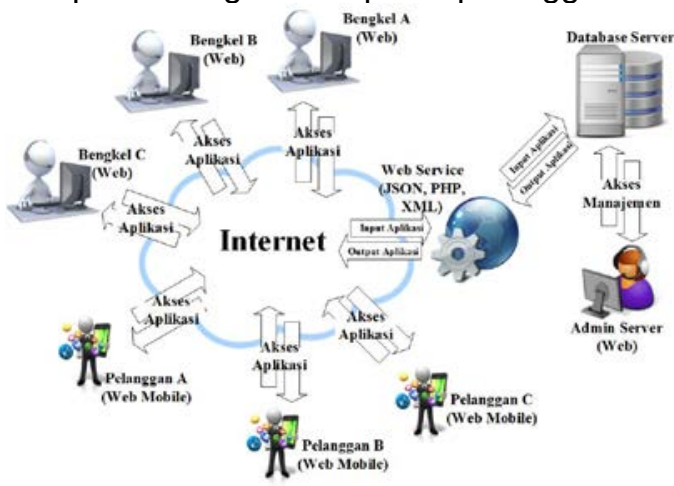

Gambar 2. Gambaran Umum Sistem

\subsection{Pemodelan Sistem}

Pemodelan sistem informasi bengkel digambarkan menggunakan data flow diagram. Gambar 3 merupakan gambar DFD Level 0 dari aplikasi reservasi service bengkel yang terdiri dari 4 proses utama yaitu proses login, manajemen data bengkel, manajemen data pelanggan, dan manajemen booking. Proses login merupakan autentifikasi untuk user yang terlibat dalam sistem baik superuser, admin bengkel, dan pelanggan. Proses login ini akan mengarahkan user ke hak akses masing-masing. Proses manajemen data bengkel merupakan proses untuk 
mengelola master data bengkel. Proses manajemen data pelanggan merupakan proses untuk mengelola master data pelanggan. Proses manajemen data booking merupakan proses untuk mengelola data booking yang dilakukan oleh

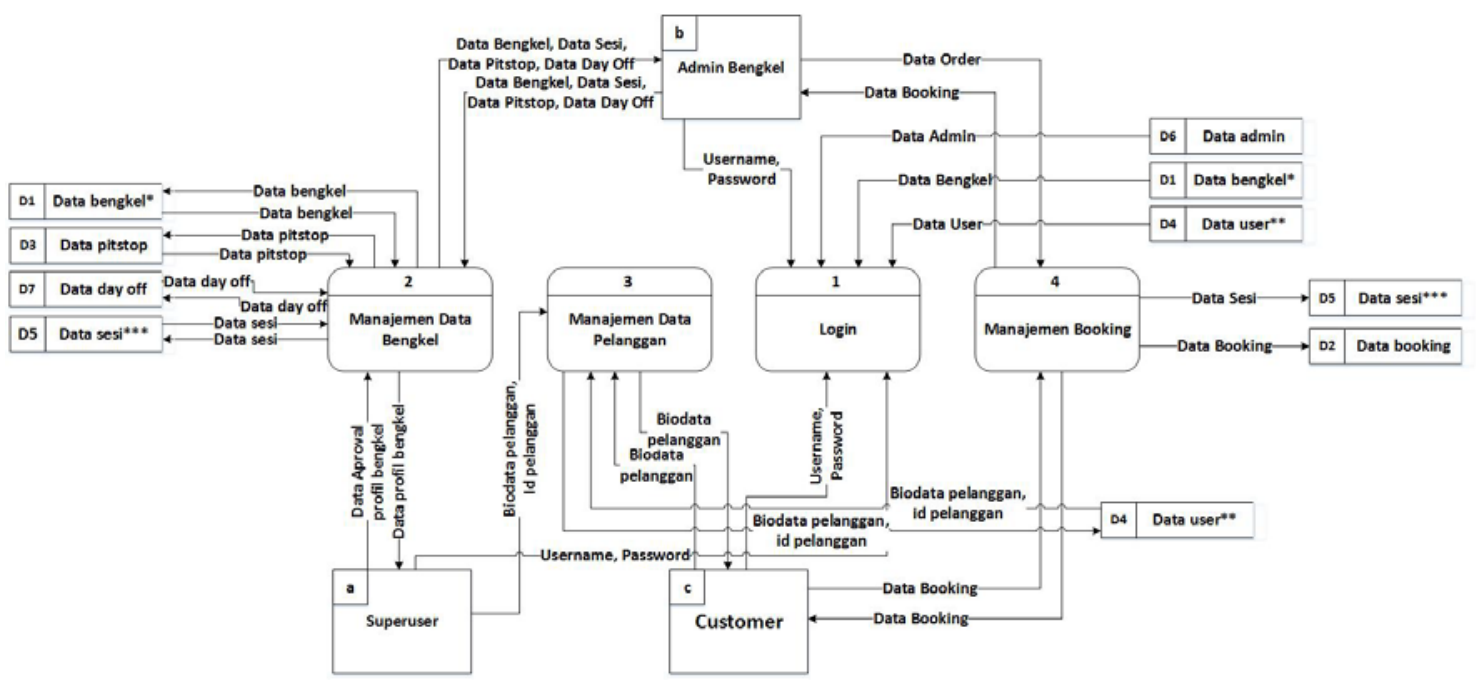

Gambar 3. DFD Level 0 Aplikasi Reservasi Service Bengkel

\subsection{Perancangan Database}

Rancangan database pada sistem
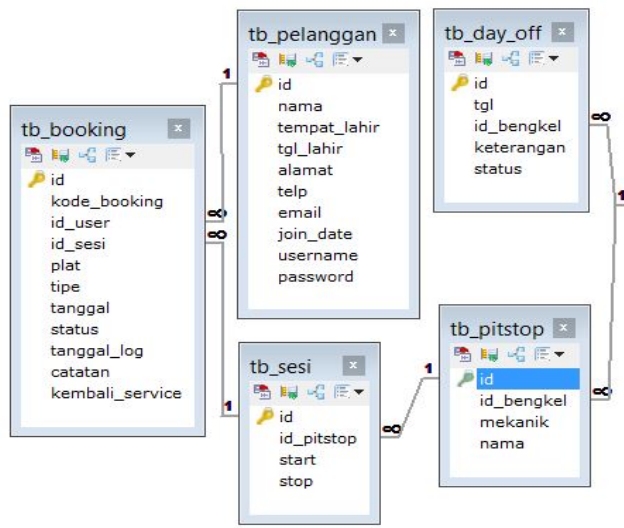

bengkel digambarkan dalam bentuk relasi antar tabel, yang ditunjukan pada Gambar 4.

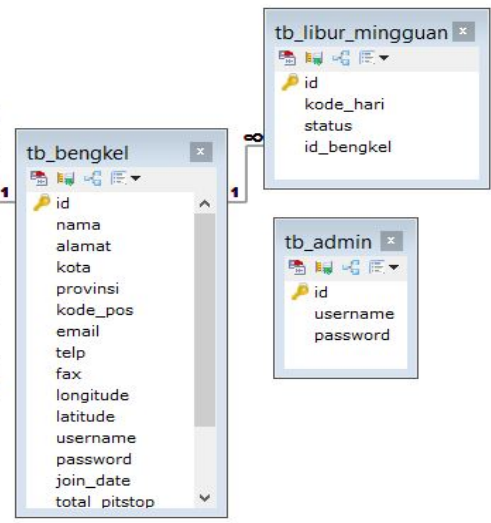

Gambar 4. Database Aplikasi Reservasi Service Bengkel

Pada rancangan database tersebut terdiri atas 8 tabel yaitu tb_pelanggan, tb_booking, tb_sesi, tb_pitstop, tb_bengkel, tb_admin, tb_libur_mingguan, dan tb_day_off.

\section{HASIL DAN PEMBAHASAN}

\subsection{Hasil}

Penelitian ini menghasilkan sebuah aplikasi reservasi service untuk bengkel sepeda motor berbasis web berupa aplikasi atau perangkat lunak yang dapat dijalankan melalui browser internet. Aplikasi ini dibangun dengan bahasa pemrograman PHP dan database MySQL yang telah didukung web responsive design. Aplikasi ini ditujukan untuk membantu dan memudahkan pihak bengkel mengatasi masalah reservasi yang masih bersifat manual, sehingga pelanggan yang ingin melakukan reservasi harus datang terlebih dahulu untuk mendapatkan antrean.

\subsection{Pembahasan}

Aplikasi reservasi service bengkel ini digunakan oleh 3 pengguna utama, yakni : 
admin bengkel, member, dan admin pengelola aplikasi. Secara umum ketiga pengguna akan memulai aplikasi pada halaman utama, seperti pada Gambar 5. Untuk menggunakan aplikasi ini, terdapat dua user yang harus melakukan registrasi yakni user sebagai admin bengkel dan user sebagai member. User sebagai bengkel harus melakukan registrasi terlebih dahulu melalui halaman registrasi bengkel seperti pada

6.

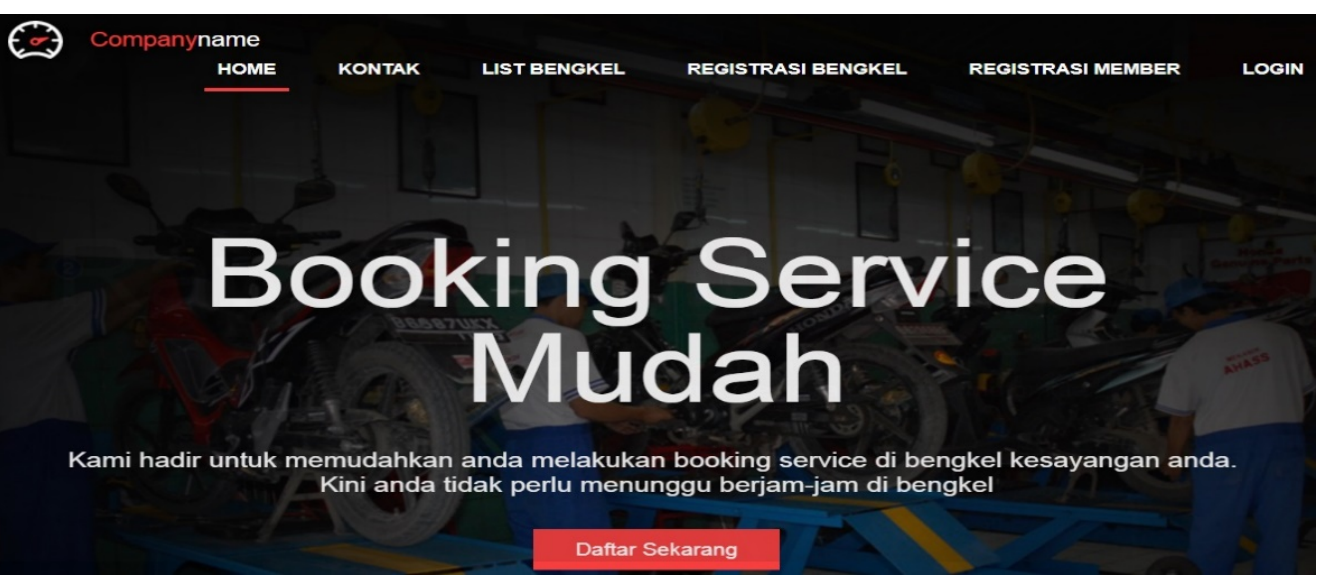

Gambar 5. Halaman Utama Aplikasi

Pengguna bengkel melakukan registrasi harus menginputkan data lengkap yang akan disimpan pada database aplikasi.

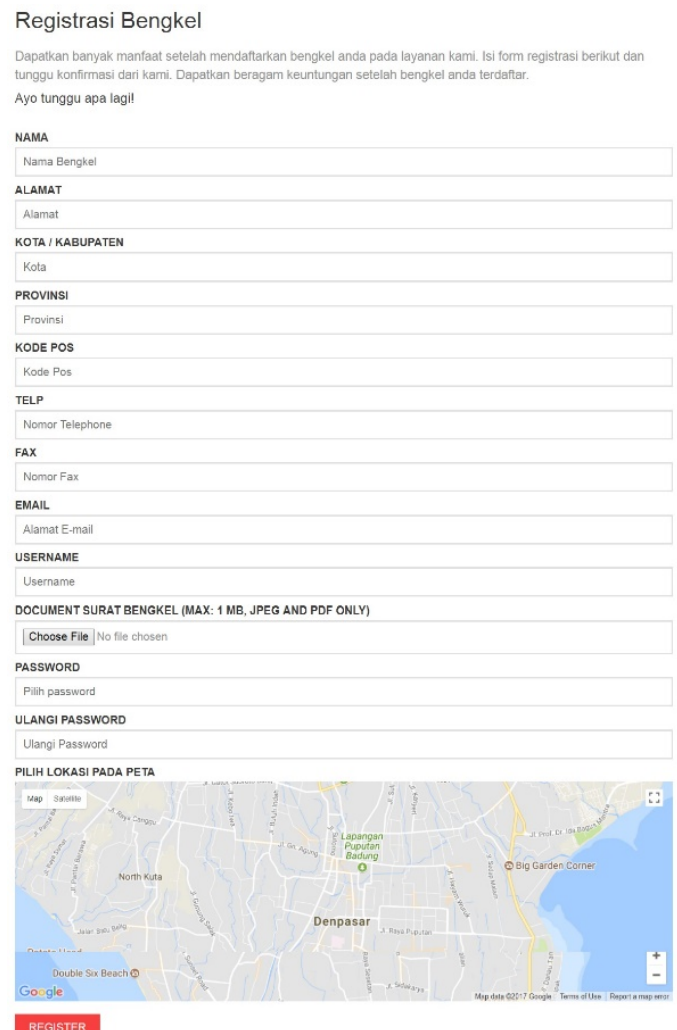

Gambar 6. Halaman Bengkel Melakukan Registrasi

Pengguna aplikasi sebagai member harus melakukan registrasi terlebih dahulu, untuk dapat menggunakan fitur yang 
tersedia. Gambar 7 merupakan halaman registrasi yang dilakukan oleh member. Registrasi Member

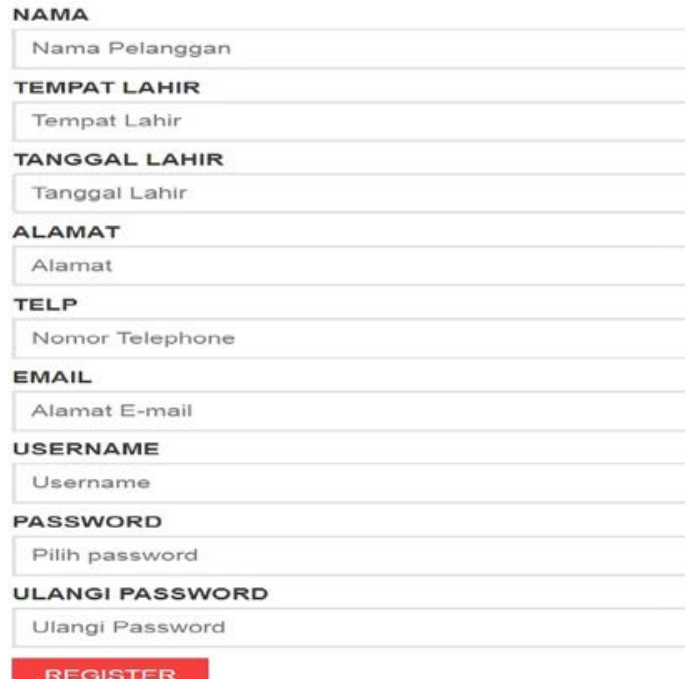

Gambar 7. Halaman Member Melakukan Registrasi

Pengguna ketiga yaitu admin pengelola aplikasi akan menggunakan halaman login yang sama dengan admin bengkel. Admin pengelola aplikasi bertugas untuk melakukan pengecekan dan melakukan konfirmasi status terhadap admin bengkel dan admin member yang telah terdaftar pada aplikasi

Gambar 8 merupakan halaman login yang dapat digunakan oleh bengkel dan admin pengelola aplikasi untuk melakukan login dengan menginputkan user id dan password yang telah didaftarkan pada saat melakukan registrasi.

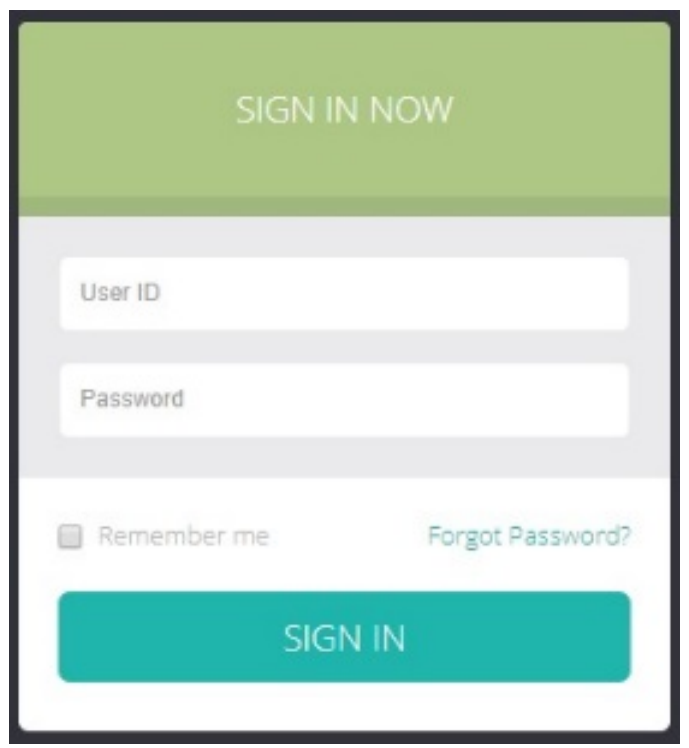

Gambar 8. Halaman Login Pengelola Aplikasi dan Bengkel

Member yang telah melakukan registrasi dan telah dikonfirmasi oleh admin pengelola aplikasi, dapat melakukan login dengan memilih menu login pada halaman utama aplikasi, sesuai dengan Gambar 5.

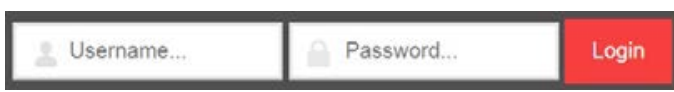

Gambar 9. Halaman Login Member

Member melakukan login dengan menginputkan username dan password yang telah didaftarkan pada saat melakukan registrasi. Gambar 9 merupakan halaman login member.

Member yang telah berhasil melakukan login dapat menikmati fitur yang telah disediakan pada aplikasi. Untuk melakukan reservasi, member dapat memilih menu list bengkel pada halaman utama aplikasi, sesuai dengan Gambar 5 .

Gambar 10 merupakan tampilan menu list bengkel pada member yang telah melakukan login pada aplikasi, terdapat 3 pilihan bengkel yang diberikan oleh aplikasi dengan ketentuan jarak terdekat dari member 


\section{List Bengkel}

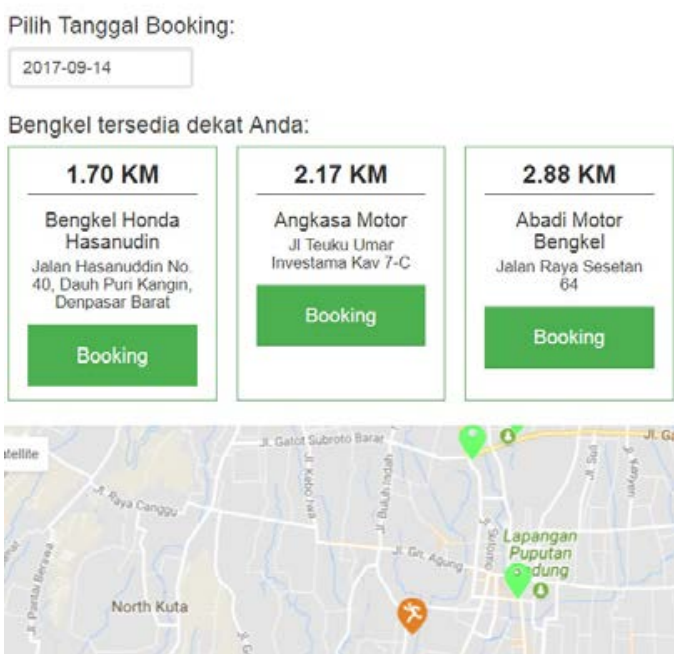

Gambar 10. Proses Member Memilih Bengkel pada Menu List Bengkel

Gambar 11 merupakan halaman untuk memilih waktu dan pitstop pada bengkel setelah member memilih bengkel yang terproses pada gambar 10 .

Bengkel Honda Hasanudin

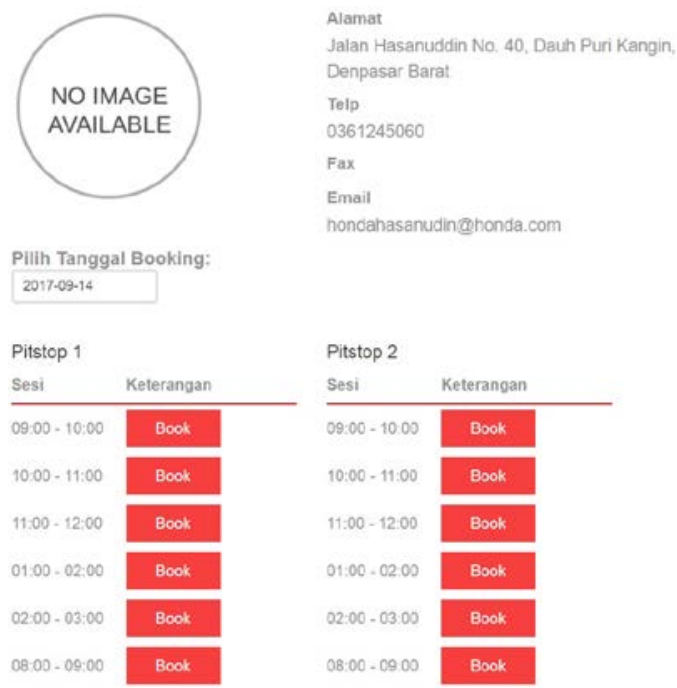

Gambar 11. Halaman Member Memilih Pitstop untuk Melakukan Reservasi

Setelah member memilih waktu dan pitstop, member menginputkan data booking yang akan diterima oleh bengkel. Hal ini dapat dilihat pada Gambar 12.

\section{Informasi Booking}

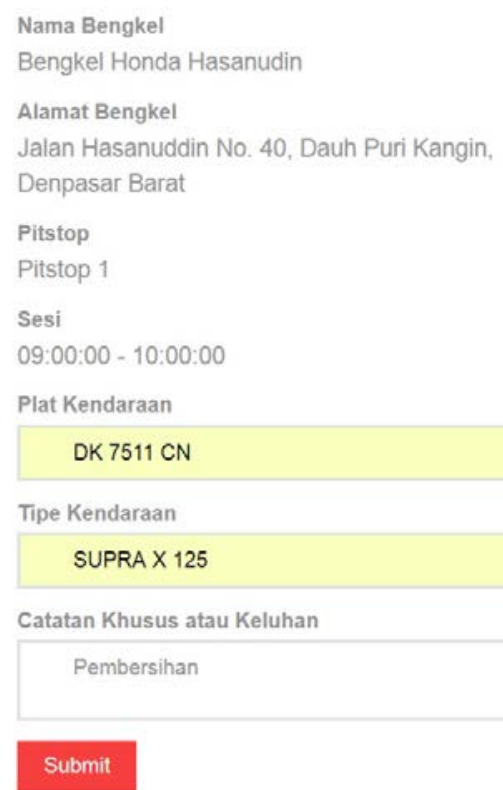

Gambar 12. Halaman Member Menginputkan Data Booking

Data booking member, berisikan informasi jam dan pitstop yang dipilih oleh member. Bengkel dapat mengubah status booking dari book menjadi done yang dapat dilihat pada Gambar 13.

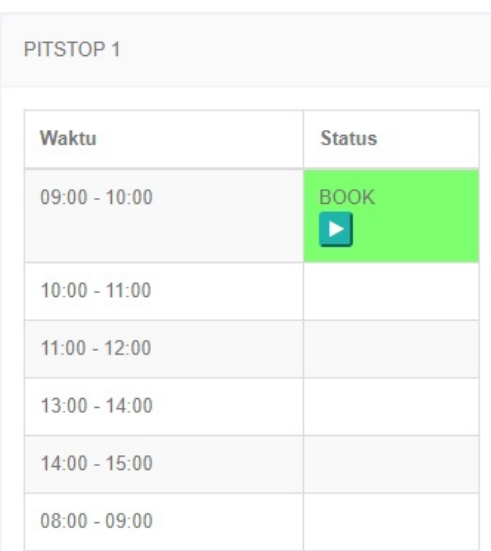

Gambar 13. Halaman Data Booking pada Bengkel

\subsection{Pengujian Sistem}

Aplikasi reservasi service untuk bengkel sepeda motor menggunakan pengujian black box dengan cara menguji beberapa fungsi yang tersedia pada aplikasi. Terdapat 4 bagian pengujian pada aplikasi reservasi service, yaitu pengujian 
halaman utama aplikasi, pengujian proses pengelola aplikasi pada aplikasi, pengujian proses bengkel pada aplikasi dan pengujian proses member pada aplikasi dan seluruh pengujian tersebut telah berjalan dan berfungsi dengan baik

\section{Kesimpulan}

Dari penelitian perangkat lunak yang telah dilakukan, aplikasi yang dihasilkan dapat mengakomodasi kebutuhan banyak bengkel untuk menyediakan layanan reservasi service. Aplikasi dapat memberikan informasi ketersediaan bengkel melalui layanan informasi geografis yang tampil pada menu list bengkel. Ketersediaan bengkel dipengaruhi oleh beberapa hal, yaitu bengkel tidak sedang off (libur) dan adanya ketersediaan pitstop pada bengkel. Bengkel yang sedang libur atau dengan status full book tidak akan tampil pada menu list bengkel dan pelanggan akan diberikan pilihan bengkel lain oleh aplikasi. Berdasarkan pengujian menggunakan metode black box seluruh fungsionalitas sistem telah berjalan dengan baik.

\section{Daftar Pustaka}

[1] Sukerti, Ni Kadek \& Pratami, Ni Wayan Cahya Ayu. 2014. Implementasi Sistem Informasi Reservasi Speedboat Berbasis Web Service Dan Sms Reply. Jurnal Sistem dan Informatika, vol. 9, No. 1, November 2014

[2] Aryani, Tris Retno. 2013. "Perancangan Sistem Informasi Reservasi dan Pelayanan Kamar pada Hotel Bumi Asih Bandung" (Tugas Akhir). Universitas Komputer Indonesia : Fakultas Teknik dan IImu Komputer

[3] Nugroho, Bunafit, 2004. Aplikasi Pemprograman Web Dinamis dengan PHP dan MySQL. Gava Media, Yogyakarta.

[4] Soeherman, Bonnie., Pinontoan, Marion. 2008. Designing Information System; Concepts \& Cases with Visio. Jakarta: Penerbit Elex Media Komputindo.

[5] Bassil, Youssef, 2012. A Simulation Model For The Waterfall Software Development Life. Interna-tional journal of Engineering \& Technology (iJET), 2(5).
[6] Aini, Anisah. 2009. Sistem Informasi Geografis Pengertian dan Aplikasinya. Yogyakarta

[7] Kindarto, Asdani. 2008. Asyik Berinternet dengan Beragam Layanan Google. Yogyakarta: Penerbit Andi. 